\title{
DETERMINANTS OF HOUSEHOLDS' E-WASTE DISPOSAL IN SOUTHWESTERN STATES, NIGERIA
}

\author{
Babatunde A. AODU ${ }^{* 1}$, Mathew O. ILORI ${ }^{2}$, Margret O. JEGEDE ${ }^{2}$ \\ ${ }^{1}$ National Centre for Technology Management, Obafemi Awolowo University, Ile Ife, Nigeria \\ ${ }^{2}$ African Institute for Science Policy and Innovation, Obafemi Awolowo University, Ile Ife, Nigeria
}

\begin{abstract}
In view of the complex composition of e-waste and its resultant implications for e-waste disposal decision among constituents, including households, at the microlevel; empirical evidences on factors predisposing consumer e-waste disposal behavior, particularly for specific e-waste category would enrich decision making on sustainable e-waste management plan in developing country context. It is on this premise/background that we examined determinants of households' e-waste disposal decision for specific e-waste categories at local level in selected States - Lagos and Oyo States, Southwestern Nigeria. Using a 2018 household data set collected through questionnaire survey, and subjected to descriptive and inferential analytical tools. This study finds differences in the factors influencing households' e-waste disposal decision between the two States and even within each states, for each e-waste category considered. Inconvenience, value reward, non-implementation/lack of e-waste legislation/policy and lack of e-waste collection/take back system were predominant determinants of households' decision to store or dispose the e-waste categories in the study area. The study result has positive implications for sustained e-waste management plan and action at local levels, and more specifically for the study area.
\end{abstract}

Keywords - determinants, disposal, e-waste, households, management, Nigeria

\section{INTRODUCTION}

Growing e-waste volume is a global issue. The peculiarity of the increasing quantity in developing countries is even more worrisome. This is on account of uncontrolled (in and out)flow of the waste and, most importantly, poor end-of-life management of Electrical and Electronic Equipment (EEE) in the global South. Consequently, e-waste management studies within the context, primarily revolves around e-waste disposal and treatment practices - which are generally unsafe, unhygienic and unwholesome. Thus, potentially hazardous to the eco-system and public health (Ding et al. 2012; Law and Covaci, 2014; Rao, 2014). In fact, a great deal of (economically) valuable materials are being lost (Grant and
Oteng-Ababio, 2012; Izatt et al., 2012) to primitive e-waste management in developing countries.

Consumers - either at stakeholders' or individual level, are major EEE users and eventually, downstream-producers of e-waste. Essentially, they play important role in e-waste management plan and actions for a given geographical location. Consumers (pro-)environmental behavior largely determines sustainable e-waste management practices within a given boundary. For instance, pro-environmental behavior often leads to very minimal damage to the environmental and public health. In view of this, there are number of research efforts on estimation, quantification and macro-level management of e-waste (Baldé et al., 2017; Baldé et al., 2015; Alavi et al., 2015; Taghipour et al., 2012; Chung et al., 2011; Steubing et al., 2010; Wager et al., 2011; Shinkuma et al., 2009; Streicher-Porte et al., 2009; Yoshida et al., 2009; Streicher-Porte et al., 2009), nonetheless, studies on microlevel determinants of e-waste management practices is relatively low in developing countries. Micro-level constituents are often primary targets of policy objectives and plan. Therefore, a probe in this research direction is germane for sustainable e-waste management plan, especially in developing countries. An inclusive and sustained e-waste management strategies is often dependent on a thorough understanding and comprehension of specific consumer (at micro-level, including households, private firm and public organizations) behavior in country and local context (Borthakur and Govind, 2017; Kwatra et al., 2013; Saphores et al., 2012).

In an attempt to understand factors influencing consumer e-waste disposal behavior, particularly at household level in developing countries. A number of suggestions have been made on factors determining household e-waste disposal decision (Borthakur, 2014; Dwivedy \& Mittal, 2013; EstradaAyub \& Kahhat, 2014; Jang, 2010; Li et al., 2012; Nnorom \& Osibanjo, 2008; O Osibanjo \& Nnorom, 2007; Oladele Osibanjo \& Nnorom, 2008; Wang et al., 2011; Xu et al., 2014), however, they are either too 'generalized' or 'scoped' in context, with little or no empirical justification. Furthermore, the literature has not taken the peculiarities and composite nature (physical and chemical) of e-waste into cognizance. E-waste items are highly polarized along size and 


\section{International Journal of Engineering Applied Sciences and Technology, 2021 \\ Vol. 5, Issue 10, ISSN No. 2455-2143, Pages 29-36 \\ Published Online February 2021 in IJEAST (http://www.ijeast.com)}

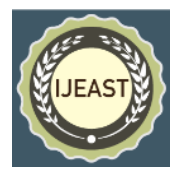

composition - (non)hazardous and (recoverable) valuable material. Logically, the extent to which households 'valorize' specific e-waste item and category could differ, on account of complex e-waste nature, intertwined with socio-economic and demographic characteristics of households. In view of this, empirical research efforts have to be made to investigate the extent to which these 'hypothetic' factors (in extant literature) influence households' e-waste management practices, especially disposal options; and more importantly, major decision factor(s) determining households' e-waste disposal for specific e-waste category.

We made research attempt in this direction, however, taking into perspective specific e-waste category. Our assumption is that e-waste item under specific category have almost or approximately similar characteristics - physical and chemical. For instance, large household e-waste items are relatively large and heavy - majorly composed of steel and irons, however, with little or no hazardous chemicals; on the contrary, IT/Telecommunication e-waste items - chief constituents being hazardous materials and (recoverable) precious metals (Kiddee et al., 2013; Robinson, 2009). Thus, the objective of this study is to:

i) identify the factors influencing consumers' e-waste disposal decision,

ii) determine the extent to which these identifiable factors influence household e-waste disposal, taking e-waste category into perspectives.

Furthermore, our study is limited to developing countries, however, laying emphasis on households' within specific Local Government Areas (LGAs) in selected states, Southwestern Nigeria. We started with a section on a concise review of literature of attributable factors influencing consumers' e-waste disposal decisions and options in developing countries. Then followed with this study's methodology section. Subsequently, a section on the result and discussion of this study. This paper is wrapped up with a concluding section.

\section{FACTORS INFLUENCING E-WASTE DESTINATIONS: A REVIEW OF LITERATURE}

In developing country context, there is a symmetric consumption pattern (growing adoption and usage) of electrical and electronic equipment, however, disproportionate options in the end of life management of these products (Borthakur, 2014; Li et al., 2012). Organizational routine and policy, and leadership could play important role in e-waste disposal options in private and public enterprises. On the contrary, households are open to more options; on account of households' socio-economic differences, and often accustomed discretion on e-waste disposal decision. E-waste disposal at all levels, especially in vast majority of developing countries, is generally inappropriate with options of landfills; refuse dumpsite; sell/give to friends, family members and relatives; second hand market; store and donation (Borthakur, 2014; Dwivedy \& Mittal, 2013; Estrada-Ayub \& Kahhat, 2014; Song et al., 2012). At the household level, literature (Borthakur, 2014; Borthakur \& Govind, 2017; Dwivedy \& Mittal, 2013; Estrada-Ayub \& Kahhat, 2014; Li et al., 2012; Nnorom et al., 2009; Nnorom \& Osibanjo, 2008; O Osibanjo \& Nnorom, 2007; Oladele Osibanjo \& Nnorom, 2008; Saphores et al., 2012; Wang et al., 2011) has suggested 'hypothetical' factors influencing households' e-waste management behavior, including disposal, in developing countries. These studies 'hypothetically' attribute factors to differing consumer behavior in e-waste management practices in developing countries situation. Thus, the need for an empirical investigation.

Borthakur (2014) examined e-waste generation and management among different stakeholders, including households in the city of Pune, India. At household level, a survey was conducted in two different areas with distinct income groups of residence; the lower and lower-middle, and upper-middle income group. Generally, this study result indicated primitive e-waste management, irrespective of the stakeholders considered for the study. The author revealed that the usual practice is to keep Old and/or unused EEE at home, which are in turned exchanged for new ones, especially during festive period. The replacement of these wastes usually peaked due to lots of exchange offers, during the season. Thus, in this study context, 'best' exchange offer (in terms of newness and/or quality) determined e-waste management decision among households in the city of Pune, India. The outcome of another independent, but empirical finding (Dwivedy \& Mittal, 2013) in India, also show that best exchange was among the most determinant factors influencing consumer ewaste disposal choices.

Furthermore, the lack of infrastructure (in terms of ewaste disposal facilities) also contributes to unwholesome ewaste management practices at all levels, in developing countries (Nnorom \& Osibanjo, 2008; O Osibanjo \& Nnorom, 2007). The availability of e-waste disposal infrastructure, and its close proximity to households enables ease of access, thus, reducing the quantity of the waste stream that flows into unwarranted destination such as landfills and dumpsites. Otherwise, households capitalize on available but unwholesome disposal choices. Developing countries, especially African countries are still generally lacking in appropriate infrastructure required for e-waste disposal. However, in Asian countries (particularly India, China and Japan) where these infrastructures are available, they are either insufficient or too distant away from consumers. Essentially, 'situational' factors, which is not only limited to available ewaste disposal infrastructure but also proximity for usage, determines households' e-waste decisions and destinations (Borthakur, 2014; Estrada-Ayub \& Kahhat, 2014; Li et al., 2012). Consumer decision to store or dispose unused computer products/goods largely depends on the availability and 


\section{International Journal of Engineering Applied Sciences and Technology, 2021 \\ Vol. 5, Issue 10, ISSN No. 2455-2143, Pages 29-36 \\ Published Online February 2021 in IJEAST (http://www.ijeast.com)}

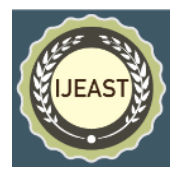

proximity of designated disposal infrastructure (Estrada-Ayub \& Kahhat, 2014). In view of this challenges, households may use other e-waste handling and management channel including storage and donation. Although, this practice may reduce the toxic flow of e-waste constituents into the ecological system, nonetheless, it restrains flow of the waste into formal recycling system; thus a potential drawback for optimum ewaste recycling capacity and business.

Moreover, consumer e-waste disposal choices could also be based on 'subjective' factors, such as e-waste size, storage space and perceived value. These factors remarkably differ among consumers and, largely a function of socio-economic environment within which individual or collectively stakeholders, operates. For instance, high income household are more likely to discard their e-waste by given or donation to (close) associates. In such situation, 'perceived' value (market, economic or financial gain) of the waste is not an important consideration at the point of disposal (Estrada-Ayub \& Kahhat, 2014). Otherwise, the waste become a traded item, sold to second hand market and individual; which "presumably", often characterized middle-lower and lower income household group. Perceived value, in the context of consumers' emotional attachment to e-waste could also influence consumers' e-waste disposal decision to store or dispose (Estrada-Ayub \& Kahhat, 2014). In addition to this, heavy e-waste items in the large e-waste category such as refrigerator, freezers, washing machine and air conditioner are more likely stored due to logistics challenges in carrying these items. Alternatively, these items are disposed on condition of little or no storage space within house premises "Inconveniences", on account of limited or no storage space. Households' decision on small e-waste items may differ due to their relatively smaller size. Thus, noticeable difference in household e-waste disposal pattern for specific e-waste category (Estrada-Ayub \& Kahhat, 2014). According to a study (Li et al., 2012), households primarily disposed large household e-waste item category (televisions, refrigerators, washing machines, air conditioners and computers) by selling to scrap dealers while small household e-waste (cell phones) were primarily store at home. Households' evaluation of ewaste disposal option often premised on 'inconveniences' and economic or financial incentives (Dwivedy \& Mittal, 2013; Manomaivibool \& Vassanadumrongdee, 2011; Nnorom et al., 2009), particularly for specific e-waste items/category.

The implementation of specific e-waste legislation and policies, primarily Extended Producers Responsibility (EPR) and Polluters Pay Principles (PPP) enhances efficient and effective e-waste management system. Basically, these policies exclusively assign specific responsibilities to stakeholders involved in e-waste generation. These policies aimed at a well-coordinated, organized and oriented actions for sustained e-waste management practices. Although the modus operandi in implementation of these policies varies - at country level, nonetheless, (e-waste) take-back (or collection) and incentive mechanism are central features. Arguably, countries (including Switzerland, UK, Germany, Spain, and Japan) with extant e-waste legislation have sufficiently cut down indiscriminate dumping of the waste to unsafe route. In contrast, the lack of e-waste legislation/policies is a major challenge to sustainable e-waste management practices in majority of developing countries (Nnorom \& Osibanjo, 2008; Osibanjo \& Nnorom, 2007). This obvious deficiency led to the growing number of informal e-waste collectors - 'epitome of e-waste management challenges in developing countries'. They have been the main conduit for discharging e-waste; and as well, chiefly engaged the use of primitive, crude and potentially hazardous techniques during material recovery process. Ultimately, the informal e-waste collectors are only driven by economic/financial gain. The resultant effect is the substantial flow of e-wastes into informal destination, in the Nigeria situation (Aodu et al., 2020). Logically, the lack of formal and properly organized e-waste collection mechanism is a major challenge to achieving sustainable e-waste management goal in Africa. E-waste legislation is an important factor influencing consumer decision to dispose or store e-waste (Estrada-Ayub \& Kahhat, 2014). Therefore, the peculiarity of e-waste collection or take back mechanism in a country has implication for e-waste management practices.

The aforementioned factors predisposed consumers' ewaste management, including disposal options; hence, a background for this study inquiry. In this study context, already identifiable factors: inconvenience (with respect to the waste size and storage space), value reward (economic or financial gain), ease and accessibility to other disposal options (informal), non-implementation/lack of e-waste legislation/policy, lack of e-waste disposal infrastructure, environment and public health consideration, emotional attachment, absence of e-waste collection/take back system and best exchange offer were linked to households' e-waste disposal decisions for specific e-waste category.

\section{METHODOLOGY}

\section{A. Study Area}

The Southwestern region is one of the six geographical zones of Nigeria, comprising six states (Lagos, Oyo, Ogun, Ondo, Osun and Ekiti States). About $60 \%$ of industries and business in Nigeria are concentrated in this region. The region is the hub of the Country's economy, with relatively dense population of industrial and business activities. Moreover, Nigeria's international trade (import and export) is deeply rooted in the region, precisely in Lagos State. This is particularly so, due to the presence of one of Africa's busiest ports - sea and air, thus, attracting significant volume of domestic and international trade. The Southwestern region is a major point of departure of tradeable goods including electrical and electronic products - new or used, to other regions of Nigeria. Furthermore, the region also has one of the highest human population, second to the Northwestern region. 
Arguably, the social and economic peculiarities of the region, and in particular, Lagos State would have corresponding influence on other regional states, especially states in close proximity to Lagos. Therefore, for the purpose of this study, two states - Lagos and Oyo States in Southwestern Nigerian was purposively selected. These study areas have the highest human population - presumably highest household density, however, with varying socio-economic and demographic characteristics in the South West.

\section{B. Study Design}

This study sampling technique was first approached from the perspective of the geopolitical zones in the two selected states. Lagos and Oyo State each comprises three senatorial districts, with twenty (20) and thirty-three (33) Local Government Areas - LGAs, respectively. On this premise, three (3) LGAs - an LGA with the highest human population per senatorial district, were purposively selected from each of the States. Eventually, Alimosho (in Lagos West), Kosofe (in Lagos East) and Surulere (in Lagos Central) in Lagos State; and Ibadan North East (in Oyo South), Egbeda (in Oyo Central) and Saki West (in Oyo North) in Oyo State, were used for this study. Furthermore, a uniform random sampling of fifty (50) households in each of the selected LGAs, which culminated to a total sample size of three hundred (300) households.

Both quantitative and qualitative methods were used for this study. Survey instrument, precisely questionnaire was used for primary data collection. However, the design of this quantitative instrument (specifically for households, and in view of the study focus), relied heavily on qualitative information in literature (as indicated in the literature review section). Household representatives, preferably household heads were the focus of the survey, thus, a questionnaire represents a household unit. The questionnaire was partitioned into two section, and in the following order: sociodemographic characteristics of households and the extent to which the identifiable factors (in literature section) influence household disposal decisions for specific e-waste category. The households' questionnaire survey (distribution and collection) was done within the last quarter of the year 2018.

At the end of this study survey, two hundred and fortytwo (242) questionnaires were retrieved, representing $80.67 \%$ of the total (300) administered. Statistical Package for Social Scientist (SPSS) version 20 was used for the analysis of the data collected. Descriptive and Inferential statistics (ANOVA and post hoc) formed the basis upon which this study result and discussion are drawn.

\section{RESULT AND DISCUSSION}

\section{A. Socio-demographic characteristics, by States.}

The socio-demographic characteristics of respondents (household representatives) and households are presented in Table $1 \mathrm{a}$ and $1 \mathrm{~b}$ respectively. This section discusses the background characteristics of households and households' respondents in the study area. The section is divided, thus;

\section{Socio-demographic characteristics of household respondents, by States.}

The socio-demographic characteristics of households' respondents is has shown in Table 1a below. The Table shows that there are more male $(58.7 \%)$ respondents than female. This pattern of gender distribution is also reflected in each of the states studied; $(62.8 \%)$ and $(54.5 \%)$ for Lagos and Oyo States respectively. Therefore, the relative share of female households' respondents encountered during the survey activities were generally low. Furthermore, the age distribution of these respondents shows that majority falls within the age bracket of 31-40 years, constituting more that $40 \%$ of the total, and the lowest share $(3.4 \%)$ being more than 60 years. Lagos and Oyo States also has similar pattern of age group distribution of respondents in the majority share, representing $(33.3 \%)$ and $(51.3 \%)$ respectively. In addition, this study result also revealed that more than $70 \%$ of the total households' respondents had at least a degree (OND/HND/B.Sc.) certificate. A similar pattern of respondents' educational profile was noticeably observed in the two states - Lagos and Oyo States. With respect to the family role of the respondents; majority were husband, representing $50.4 \%$ for Lagos state and $42.1 \%$ for Oyo state.

\section{Socio-demographic Characteristics of Households by States}

The socio-demographic characteristic of households surveyed for this study is has shown in Table $1 \mathrm{~b}$. This section discusses the general and specific background characteristics of the surveyed households. Table $1 \mathrm{~b}$ reveals that the majority $(32.3 \%)$ of the total households (for both States) surveyed has four (4) household members; likewise, in the respective states - 35.4\% and $29.7 \%$ for Lagos and Oyo States respectively. Furthermore, the Table also shows that majority of the total household respondents (for both, and each states) had at most 2 household members in active job. However, a significantly large numbers $(45.6 \%)$ of household members in Lagos State had more than 3 members in active job compared with household members $(10.3 \%)$ in Oyo State. The unique socioeconomic characteristics of Lagos state (being the commercial and business hub of Nigeria) could account for the disproportionate number of household members in active job between the two states.

Table-1a Socio-economic characteristics of Households' respondents

\begin{tabular}{llll}
\hline Variable & $\begin{array}{l}\text { Lagos State } \\
\text { Freq. }(\%)^{*}\end{array}$ & $\begin{array}{l}\text { Oyo State } \\
\text { Freq. }(\%)^{*}\end{array}$ & $\begin{array}{l}\text { Total } \\
\text { Freq. } \\
* *\end{array}$ \\
\hline $\begin{array}{l}\text { Gender } \\
\text { Male }\end{array}$ & $76(62.8)$ & $66(54.5)$ & $142(58.7)$ \\
Female & $45(37.2)$ & $55(45.5)$ & $100(41.3)$
\end{tabular}

Age Group (years) 


$\begin{array}{llll}20 & 3(2.6) & 7(5.9) & 10(4.2) \\ 21-30 & 22(18.8) & 19(16.0) & 41(17.4) \\ 31-40 & 39(33.3) & 61(51.3) & 100(42.4) \\ 41-50 & 26(22.2) & 24(20.2) & 50(21.2) \\ 51-60 & 24(20.5) & 3(2.5) & 27(11.4) \\ >60 & 3(2.6) & 5(4.2) & 8(3.4)\end{array}$

Highest Educational

Attainment

\begin{tabular}{llll} 
No formal Education & $1(0.9)$ & $0(0.0)$ & $1(0.4)$ \\
Junior secondary & $1(0.9)$ & $1(0.8)$ & $2(0.8)$ \\
Senior secondary & $16(13.9)$ & $15(12.4)$ & $31(13.1)$ \\
OND/HND/B.Sc. & $63(54.8)$ & $67(55.4)$ & $130(55.1)$ \\
M.Sc./M. Phil. /PhD & $34(29.6)$ & $38(31.4)$ & $72(30.5)$ \\
Household Role & & & \\
Husband & $60(50.4)$ & $48(42.1)$ & $108(46.4)$ \\
$\begin{array}{l}\text { Housewife } \\
\text { Others }\end{array}$ & $28(23.5)$ & $45(39.5)$ & $73(31.3)$ \\
& $31(26.1)$ & $21(18.4)$ & $52(22.3)$ \\
Total & $\mathbf{1 1 9}$ & $\mathbf{1 1 4}$ & $\mathbf{2 3 3}$ \\
\hline Table 1a shows & the socio-economic distribution of
\end{tabular}

households' respondents in Lagos and Oyo States

N B: * (within each States); ** (for both states).

Source: Author's Survey, 2018.

Moreover, the total occupation distribution (in terms of the number of counts per occupation category) reveals that $44.5 \%$ of total household members (in both states) in active job were civil servants. This constitutes the largest share for households' member occupational profile. This pattern of household member occupation distribution is also reflected in the respective states; the largest share being $33.3 \%$ and $54.7 \%$, for Lagos and Oyo States, respectively.

\section{B. Factors Influencing Choices of E-waste Disposal Techniques among Households in Lagos and Oyo States (2013-2018).}

This section discusses some of the determinants of households' disposal decisions on specific e-waste category as presented in Table 3. Using a confidence level of $95 \%$, the extent to which these factors influenced households' e-waste disposal decisions for the respective States were also discussed. Consequently, we contextualized households' ewaste disposal decision factors for each e-waste category and for the respective States.

Table - 1b Socio-economic Characteristics of Households

\begin{tabular}{llll}
\hline & $\begin{array}{l}\text { Lagos State } \\
\text { Variable }\end{array}$ & Oyo State & Total \\
& Freq. $(\%)^{*}$ & Freq. $(\%)^{*}$ & $\begin{array}{l}\text { Freq. }(\%) \\
* *\end{array}$ \\
\hline Household size & & & \\
1 & $4(4.0)$ & $8(6.8)$ & $12(5.5)$ \\
2 & $10(10.1)$ & $9(7.6)$ & $19(8.8)$ \\
3 & $10(10.1)$ & $10(8.5)$ & $20(9.2)$ \\
4 & $35(35.4)$ & $35(29.7)$ & $70(32.3)$ \\
5 & $13(13.1)$ & $28(23.7)$ & $41(18.9)$ \\
6 & $12(12.1)$ & $16(13.6)$ & $28(12.9)$ \\
7 & $10(10.1)$ & $10(8.5)$ & $20(9.2)$
\end{tabular}

$>7$

$5(5.1)$

$2(1.7)$

$7(3.2)$

No of Household

workers

$\leq 2$

$>2 \leq 4$

$>4$

48 (46.6)

47 (45.6)

8 (7.8)

$101(87.1)$

$12(10.3)$

3 (2.6)

$149(68.0)$

59 (27.9)

$11(5.0)$

\section{Total Occupation}

Density

Civil Servant

Private/Non-profit

Self employed

Retiree

$72(33.3)$
$82(38)$
$55(25.5)$

$129(54.7)$

$56(23.7)$

$37(15.7)$

$14(5.9)$

$201(44.5)$

$138(30.5)$

92 (20.4)

21 (4.6)

(Aggregate) Monthly

Income

$<50,000$

$50,000-100,000$

100,001-150,000

150,001-200,000

$200,001-250,000$

250,001-300,000

$300,001-350,000$

$>350,001$

$11(9.6)$
$22(19.1)$
$34(29.6)$
$21(18.3)$
$19(16.5)$
$2(1.7)$
$4(3.5)$
$2(1.7)$

$2(1.7)$

16 (13.2)

$31(25.6)$

$47(38.8)$

15 (12.4)

5(4.1)

$5(4.1)$

$0(0)$

$13(5.5)$

$38(16.1)$

$65(27.5)$

$68(28.8)$

$34(14.4)$

$7(3.0)$

$9(3.8)$

2(0.8)

Total

115

121

236

Table 1b shows the socio-economic distributions of the households in Lagos and Oyo States

N.B: * (within each States); ** (for both states)

Source: Author's Survey, 2018.

The result of this study (as in Table 2a) shows that for the households in Lagos State, there is no statistical significant difference $(p>0.05)$ in the factors influencing household ewaste disposal decision for large household $(\mathrm{p}=0.871)$; small household $(\mathrm{p}=0.709)$; consumer $(\mathrm{p}=0.579)$; and IT/Telecommunication $(\mathrm{p}=0.987)$; e-waste category. On the contrary, there is a significant difference $(p<0.005)$ in the factors influencing e-waste disposal decisions for the households in Oyo State (as shown in Table 2b), with $\mathrm{p}=$ 0.000 (at 95\% confidence level) for large household; small household; consumer; and IT/Telecommunication; e-waste category.

Moreover, and specifically for respondents in Oyo State, a post hoc result (as in Table 3) indicated that there is a statistical significant difference $(p=0.000)$ between inconvenience and all other factors considered for this study. Inconvenience (2.7143) was the most important factor influencing household disposal decision on large household ewaste category. Although all other factors also had slight effects on households' e-waste disposal decision, inconvenience (with respect to the size of and storage space for large household e-waste category) was a prime disposal decision factor among the households in Oyo State. The Table also revealed that there is no statistical significant difference ( $p>0.005$ ) between; value reward, lack of e-waste disposal infrastructure, best exchange offer and absence of e-waste collection/take back system; and ease/accessibility, lack of e- 
waste legislation/policy, environment and public health consideration and emotional attachment.

In the case of factors influencing Oyo State Household's decision on small household e-waste category, Table 3 revealed that there is a statistical significant difference $(\mathrm{p}<$ $0.005)$ between: inconvenience (2.0693), lack of e-waste infrastructure (1.9901) and absence of e-waste collection/takeback system (2.0612); value reward (1.7723) and lack of ewaste disposal infrastructure (1.9901); environment and public health consideration (1.4554), emotional attachment (1.2475) and best exchange offer (1.4356); ease and accessibility (1.5000) and non-implementation/lack of e-waste legislation/policy (1.5743). Thus, inconvenience and absence of e-waste collection/take-back system were the most important factors that influenced household e-waste decision on small household e-waste category.

Furthermore and with respect to disposal decision factors influencing Households' in Oyo State on consumer e-waste category, the Table revealed statistical significant difference ( $\mathrm{p}<0.005$ ) between; Inconvenience (2.0594), value reward (1.9109), lack of e-waste disposal infrastructure (1.9802) and absence of e-waste collection/take-back system (2.0198); ease and accessibility (1.5200), lack of e-waste legislation/policy (1.6337), environment and public health consideration (1.5152) and best exchange offer (1.5347); and emotional attachment (1.2525). Inconvenience and absence of e-waste collection/take-back system were the most important factor determining Oyo State household's decisions on consumer ewaste disposal options.

Best exchange offers and value reward were the major factors influencing households' e-waste disposal decision for IT/Telecommunication e-waste category (as indicated in Table 3 ) in Oyo State. There is statistical significant difference ( $<$ $0.005)$ between; best exchange offers (2.3879); value reward (2.1111); lack of e-waste disposal infrastructure (1.8120), absence of e-waste collection/take back system (1.8205) and inconvenience (1.7586); environment and public health consideration (1.5641), lack of e-waste legislation/policy (1.4397), ease and accessibility (1.3839); and emotional attachment (1.1795) (as shown in Table 3 below).

\begin{tabular}{llllll}
\hline $\begin{array}{l}\text { Consumer Household } \\
\text { E-waste }\end{array}$ & & & & & \\
Between Groups & 4.42 & 8 & 0.55 & 0.83 & 0.579 \\
Within Groups & 636.10 & 965 & 0.66 & & \\
TOTAL & 640.52 & 973 & & & \\
& & & & & \\
$\begin{array}{l}\text { IT/Telecommunication } \\
\text { Household E-waste }\end{array}$ & & & & & \\
Between Groups & 1.48 & 8 & 0.19 & 0.22 & 0.987 \\
Within Groups & 817.64 & 985 & 0.83 & & \\
TOTAL & 819.12 & 993 & & &
\end{tabular}

Table 2a shows no significant differences among the factors for each of the e-waste category, particularly for subjects in Lagos State.

Source: Author's Survey, 2018

Table - 2b ANOVA Table for Households in Oyo State

\begin{tabular}{|c|c|c|c|c|c|}
\hline E-waste Category & $\begin{array}{l}\text { Sum of } \\
\text { Squares }\end{array}$ & df & $\begin{array}{l}\text { Mean } \\
\text { Square }\end{array}$ & $\mathrm{F}$ & Sig. \\
\hline \multicolumn{6}{|l|}{$\begin{array}{l}\text { Large Household E- } \\
\text { waste }\end{array}$} \\
\hline Between Groups & 156.90 & 8 & 19.61 & 25.42 & 0.000 \\
\hline Within Groups & 764.59 & 991 & 0.772 & & \\
\hline TOTAL & 921.50 & 999 & & & \\
\hline \multicolumn{6}{|l|}{$\begin{array}{l}\text { Small Household E- } \\
\text { waste }\end{array}$} \\
\hline Between Groups & 74.50 & 8 & 9.31 & 13.39 & 0.000 \\
\hline Within Groups & 623.29 & 896 & & & \\
\hline TOTAL & 697.79 & 904 & & & \\
\hline \multicolumn{6}{|l|}{$\begin{array}{l}\text { Consumer Household } \\
\text { E-waste }\end{array}$} \\
\hline Between Groups & 65.23 & 8 & 8.15 & 10.78 & 0.000 \\
\hline Within Groups & 1259.229 & 1166 & 1.080 & & \\
\hline TOTAL & 1287.342 & 1176 & & & \\
\hline \multicolumn{6}{|l|}{$\begin{array}{l}\text { IT/Telecommunication } \\
\text { Household E-waste }\end{array}$} \\
\hline Between Groups & 130.78 & 8 & 16.35 & 23.57 & 0.000 \\
\hline Within Groups & 718.50 & 1036 & 0.694 & & \\
\hline TOTAL & 849.29 & 1044 & & & \\
\hline
\end{tabular}

Table $2 \mathrm{~b}$ shows significant differences among the factors for each of the e-waste category, particularly for subjects in Oyo State.

Source: Author's Survey, 2018

Table - 2a ANOVA Table for Households in Lagos State

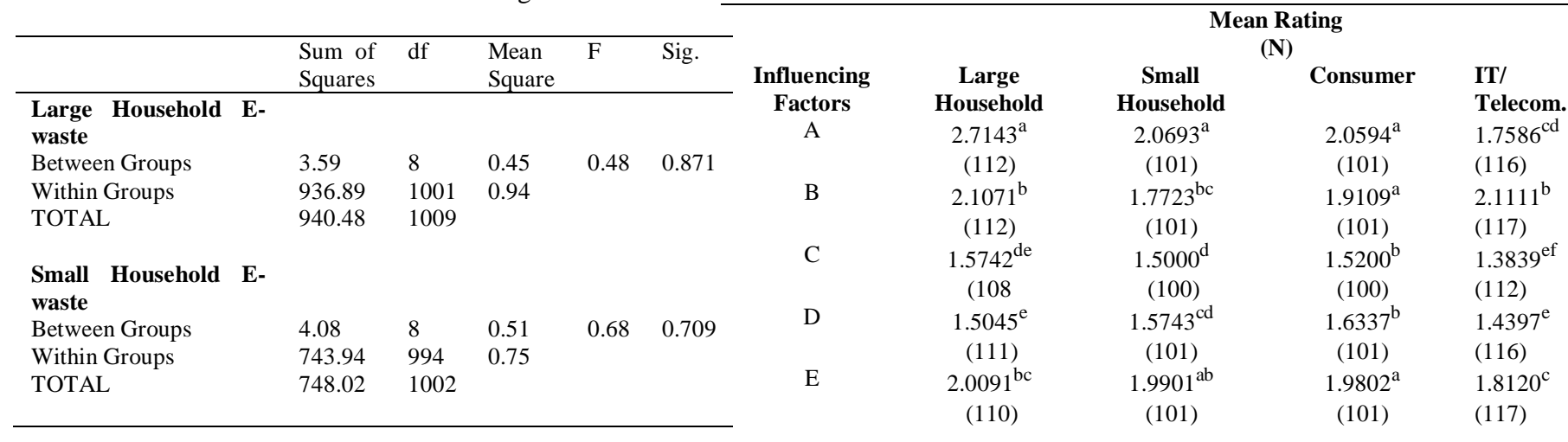




$\begin{array}{lcccll}\mathrm{F} & 1.5405^{\mathrm{e}} & 1.4554^{\mathrm{de}} & 1.5152^{\mathrm{b}} & 1.5641^{\mathrm{de}} & \\ & (111) & (101) & (99) & (117) & \\ \mathrm{G} & 1.3571^{\mathrm{e}} & 1.2475^{\mathrm{e}} & 1.2525^{\mathrm{c}} & 1.1795^{\mathrm{f}} & \\ & (112) & (101) & (99) & (117) & {[1]} \\ \mathrm{H} & 1.8036^{\mathrm{cd}} & 2.0612^{\mathrm{a}} & 2.0198^{\mathrm{a}} & 1.8205^{\mathrm{c}} & \\ & (112) & (98) & (101) & (117) & \\ \mathrm{I} & 2.0268^{\mathrm{bc}} & 1.4356^{\mathrm{de}} & 1.5347^{\mathrm{b}} & 2.3879^{\mathrm{a}} & \\ & (112) & (101) & (101) & (116) \\ \end{array}$

Table 3 shows the exact differences in the factors influencing households' e-waste disposal decisions for each e-waste category, at a confidence level of $95 \% \quad(5 \%$ level of significance).

\section{N B:}

- a, b, c, d, e, f Duncan Multiple Range Test for homogenous subsets of ratings.

- A - Inconvenience, B - Value Reward, C - Ease and Accessibility to informal disposal options, D - Nonimplementation/lack of e-waste legislation/policy, E - Lack of e-waste disposal infrastructure, F Environment and Public health consideration, $\mathrm{G}-$ Emotional attachment, $\mathrm{H}$ - Absence of e-waste collection/take back system and I - Best exchange offer.

Source: Author's Survey, 2018

\section{CONCLUSION}

This study examined determinants of household e-waste disposal decision in two Southwestern States - Lagos and Oyo States, Nigeria. The outcome of this comparative study relied on suggested determinants of consumer behavior, specifically as it concerns e-waste disposal decisions and options. However, we took a step further and empirically tested the extent to which these factors influenced consumer behavior at micro-level, using household as case study, and in relation to five e-waste categories - large household, small household, consumer and IT/Telecommunication e-waste. Based on this research study, inconvenience, value reward, ease and accessibility, non-implementation/lack of e-waste legislation/policy, lack of e-waste disposal infrastructure, environment and public health implication, emotional attachment, absence of e-waste collection/take back system and best exchange offer, had influenced households' disposal decision for all the e-waste categories in both states. More importantly, inconvenience, value reward, lack of e-waste collection/take back system and best exchange offer are the predominant factors that influenced subjects' e-waste decision in the study area, in Oyo State. This study outcome has positive implications for policy and action plan towards sustainable e-waste management in the study areas. Thus, local authorities in the respective areas of study should take into cognizance these varying and important factors, particularly as it concerns households, for future e-waste management decision making.

\section{REFERENCE}

[1] Baldé, C. P., Forti V., Gray, V., Kuehr, R., and Stegmann, P. (2017). The Global E-waste Monitor -United Nations University (UNU), International Telecommunication Union (ITU) \& International Solid Waste Association (ISWA), Bonn/Geneva/Vienna. ISBN Electronic Version: 978-92-808-9054-9. ISSN 2522-7033.

[2] Baldé, C. P., Wang, F., Kuehr, R., and Huisman, J. (2015). The global e-waste monitor - 2014, United Nations University, IAS - SCYCLE, Bonn, Germany. ISBN Electronic Version: 978-92-808-4556-3.

[3] Borthakur, A. (2014). Generation and management of electronic waste in the city of Pune, India. Bulletin of Science, Technology and Society, 34(1-2), (pp.43-52). https://doi.org/10.1177/0270467614541242.

[4] Borthakur, A., \& Govind, M. (2017). Emerging trends in consumers' E-waste disposal behavior and awareness: A worldwide overview with special focus on India. Resources, Conservation and Recycling, 117, (pp.102113). https://doi.org/10.1016/j.resconrec.2016.11.011.

[5] Chung, S. -s., K. -y. Lau, and C. Zhang. (2011). Generation of and control measures for, e-waste in Hong Kong. Waste Manage. 31, (pp.544-554). DOI: 10.1016/j.wasman.2010.10.003

[6] Ding, L., Li, Y., et al. (2012). Seasonal trend of ambient PCDD/Fs in Tianjin City, northern China using active sampling strategy. Journal of Environmental Sciences. 24 (11), (pp.1966-1971).

[7] Dwivedy, M., \& Mittal, R. K. (2013). Willingness of residents to participate in e-waste recycling in India. Environmental Development, 6(1), (pp.48-68). https://doi.org/10.1016/j.envdev.2013.03.001.

[8] Estrada-Ayub, J. A., \& Kahhat, R. (2014). Decision factors for e-waste in Northern Mexico: To waste or trade. Resources, Conservation and Recycling, 86, (pp.93-106). https://doi.org/10.1016/j.resconrec.2014.02.012.

[9] Grant, R., and Oteng-Ababio, M. (2012). Mapping the invisible and real "African" economy: Urban e-waste circuitry. Urban Geography. 33 (1), (pp.1-21).

[10] Jang, Y. C. (2010). Waste electrical and electronic equipment (WEEE) management in Korea: Generation, collection, and recycling systems. Journal of Material Cycles and Waste Management, 12(4), (pp.283-294). https://doi.org/10.1007/s10163-010-0298-5.

[11] Law, R. J., Covaci, A., Harrad, S., Herzke, D., Abdallah, M. A. E., Fernie, K., Toms, L. M. L., and Takigami, H. (2014). Levels and trends of PBDEs and HBCDs in the global environment: Status at the end of 2012. Environment International. 65, (pp.47-158).

[12] Li, J., Liu, L., Ren, J., Duan, H., \& Zheng, L. (2012). Behavior of urban residents toward the discarding of 


\section{International Journal of Engineering Applied Sciences and Technology, 2021 \\ Vol. 5, Issue 10, ISSN No. 2455-2143, Pages 29-36 \\ Published Online February 2021 in IJEAST (http://www.ijeast.com)}

waste electrical and electronic equipment: A case study in Baoding, China. Waste Management and Research, 30(11), https://doi.org/10.1177/0734242X12456728. (pp.1187-1197).

[13] Manomaivibool, P., \& Vassanadumrongdee, S. (2011). Extended Producer Responsibility in Thailand: Prospects for Policies on Waste Electrical and Electronic Equipment. Journal of Industrial Ecology, 15(2), (pp.185205). https://doi.org/10.1111/j.1530-9290.2011.00330.x.

[14] N. E. Izatt, S. R. Izatt and R. L. Bruening (2012). "Green procedure for the selective recovery of precious, specialty, and toxic metals from electronic wastes," 2012 Electronics Goes Green 2012+. Institute of Electrical and Electronics Engineers (IEEE) conference on, (pp. 1-6).

[15] Nadali Alavi, Mohammad Shirmardi, Aliakbar Babaei, Afshin Takdastan and Nastaran Bagheri (2015). Waste electrical and electronic equipment (WEEE) estimation: A case study of Ahvaz City, Iran, Journal of the Air \& Waste Management Association, 65 (3), (pp.298-305). DOI: $10.1080 / 10962247.2014 .976297$

[16] Nnorom, I. C., \& Osibanjo, O. (2008). Overview of electronic waste (e-waste) management practices and legislations, and their poor applications in the developing countries. 52 , (pp.843-858). https://doi.org/10.1016/j.resconrec.2008.01.004.

[17] Nnorom, I. C., Ohakwe, J., \& Osibanjo, O. (2009). Survey of willingness of residents to participate in electronic waste recycling in Nigeria - A case study of mobile phone recycling. Journal of Cleaner Production, 17(18), https://doi.org/10.1016/j.jclepro.2009.08.009.

(pp.1629-1637).

[18] Osibanjo, O, \& Nnorom, I. C. (2007). The Challenges of Electronic Waste (e-waste) Management in Developing Countries. Waste Management \& Research. https://doi.org/10.1177/0734242X07082028.

[19] Osibanjo, Oladele, \& Nnorom, I. C. (2008). Material flows of mobile phones and accessories in Nigeria: Environmental implications and sound end-of-life management options. Environmental Impact Assessment Review, 28(2-3), (pp.198-213). https://doi.org/10.1016/j.eiar.2007.06.002.

[20] Rao, L. N. (2014). Environmental impact of uncontrolled disposal of e-wastes. International Journal of Chemical Technology Research. 6 (2), (pp. 1343-1353).

[21] Saphores, J. D. M., Ogunseitan, O. A., \& Shapiro, A. A. (2012). Willingness to engage in a pro-environmental behavior: An analysis of e-waste recycling based on a national survey of U.S. households. Resources, Conservation and Recycling, 60, (pp. 49-63). https://doi.org/10.1016/j.resconrec.2011.12.003.

[22] Shinkuma, T., and Nguyen Thi Minh, H. (2009). The flow of e-waste material in the Asian region and a reconsideration of international trade policies on e-waste.
Environmental Impact Assessment Review 29: (pp.2531).

[23] Song, Q., Wang, Z., \& Li, J. (2012). Residents' behaviors, attitudes, and willingness to pay for recycling e-waste in Macau. Journal of Environmental Management, 106, (pp.8-16). https://doi.org/10.1016/j.jenvman.2012.03.036

[24] Steubing, B., Boni, H., Schluep, M., Silva, U., and Ludwig, C. (2010). Assessing computer waste generation in Chile using material flow analysis. Waste Management 30, (pp.473-482).

[25] Streicher-Porte, M., Marthaler, C., Boni, H., Schluep, M., Camacho, A., and Hilty, L.M. (2009). One laptop per child, local refurbishment or overseas donations? Sustainability assessment of computer supply scenarios for schools in Colombia. Journal of Environmental Management 90, (pp.3498-3511).

[26] Taghipour, H., P. Nowrouz, M. A., Jafarabadi, J., Nazari, A. A., Hashemi, M. Mosaferi, and R. Dehghanzadeh (2012). E-waste management challenges in Iran: Presenting some strategies for improvement of current conditions. Waste Manage. Res. 30, (pp.1138-1144). DOI: $10.1177 / 0734242 \times 11420328$

[27] Wager, P. A., Hischier, R., and Eugster, M., (2011). Environmental impacts of the Swiss collection and recovery systems for waste electrical and electronic equipment (WEEE): a follow-up. Science of the Total Environment 409: 1746-1756.

[28] Wang, Z., Zhang, B., Yin, J., \& Zhang, X. (2011). Willingness and behavior towards e-waste recycling for residents in Beijing city, China. Journal of Cleaner Production, 19(9-10), (pp.977-984). https://doi.org/10.1016/j.jclepro.2010.09.016.

[29] Xu, F., Wang, X., Sun, X., \& Abdullah, A. T. M. (2014). Influencing factors and moderating factors of consumers' intentions to participate in e-waste recycling. 11th International Conference on Service Systems and Service Management, ICSSSM 2014 - Proceeding. https://doi.org/10.1109/ICSSSM.2014.6874096.

[30] Yoshida, A., T. Tasaki, and A. Terazono. (2009). Material flow analysis of used personal computers in Japan. Waste Manage.29, (pp.1602-1614). DOI:10.1016/j. wasman.2008.10.021 